\title{
Formulation of yellow pumpkin cookies with mocaf (modified cassava flour) flour addition as a snack for the obese community
}

\author{
*Mustika, A.R. and Kartika, W.D. \\ Ngudi Waluyo University, Faculty of Health, Jl. Diponegoro No.186 Ungaran District, Semarang, \\ Indonesia
}

\author{
Article history: \\ Received: 28 December 2019 \\ Received in revised form: 18 \\ February 2020 \\ Accepted: 20 April 2020 \\ Available Online: 30 May \\ 2020
}

Keywords:

Cookies,

Yellow Pumpkin,

Mocaf flour,

Obesity,

High fibre

DOI:

https://doi.org/10.26656/fr.2017.4(S3).S02

\begin{abstract}
Cookies are generally made from wheat flour that provides high energy but low in fibre. Wheat flour can be substituted with yellow pumpkin flour to make cookies. Yellow pumpkin is an Indonesian local food which contains high beta carotene and fibre. The purpose of this research was to compare the yellow pumpkin and mocaf flour cookies with wheat flour cookies in terms of acceptability and nutrient content. For this experiment, two formulations were used: Formulation 1 (F1), 1: 2 ratio of yellow pumpkin flour to mocaf flour and Formulation 2 (F2), 1: 2 ratio of yellow pumpkin flour to wheat flour. Proximate analysis of the cookies was conducted. The results showed that the yellow pumpkin and mocaf flour cookies had a total energy content of $459.71 \mathrm{kcal} / 100 \mathrm{~g}$, protein content of $1.12 \mathrm{~g} / 100 \mathrm{~g}$, fat content of $36.35 \mathrm{~g} / 100 \mathrm{~g}$, fibre content of $43.59 \mathrm{~g} / 100 \mathrm{~g}$ and carbohydrate content of $31.94 \mathrm{~g} / 100 \mathrm{~g}$ whereas the yellow pumpkin and wheat flour cookies had a total energy content of $587.72 \mathrm{kcal} / 100 \mathrm{~g}$, protein content of $4.79 \mathrm{~g} / 100 \mathrm{~g}$, fat content of $40.87 \mathrm{~g} / 100 \mathrm{~g}$, fibre content of $21.42 \mathrm{~g} / 100 \mathrm{~g}$ and carbohydrate content of $50.19 \mathrm{~g} / 100$. The data collected from the acceptance test conducted with 25 panellists showed that there was no difference in the colour, texture, taste and aroma for both formulated cookies.
\end{abstract}

\section{Introduction}

Yellow pumpkin is one of the abundant agricultural commodity products in Indonesia. The number of pumpkin productions in 2011 reached 150,000 tons/year in Indonesia and specifically on Java Island, the production number was 6100 tons/year (Statistics Indonesia, 2012). Yellow pumpkin is rich in $\beta$ carotene, vitamins, minerals and fibre. Efforts to utilize the yellow pumpkin have been done by processing the fresh yellow pumpkin into flour. Pumpkin flour is currently being researched and used as a flour substitute in making bakery products such as cookies, muffins, brownies and cakes (Rismaya et al., 2018).

Yellow pumpkin flour can be categorized as a highfibre food because it meets the requirements whereby the minimum food fibre content should be $6 \mathrm{~g} / 100 \mathrm{~g}$ (Foschia, 2013). The previous study showed that the total fibre content of pumpkin flour was $14.81 \%$, whereas according to other studies, the total fibre content of pumpkin flour was higher, which was $21.39 \%-21.41$ (Purnamasari and Putri, 2015). Mocaf (modified cassava flour) flour is also commonly used in bakery products to substitute wheat flour in food product development. Mocaf flour is made from cassava fermented with lactic acid bacteria (LAB). Compared to wheat flour, the fibre content in mocaf flour is higher (Hanifa et al., 2013) but low in gluten content (Tanjung and Kusnadi, 2015). In addition, cassava is affordable and widely available.

Obesity is one of the nutritional problems in Indonesia. Basic Health Research (2018) showed that the prevalence of obesity at $>18$ years old is $21.8 \%$. Obesity is related to low fibre intake, sedentary lifestyle, high fat and high energy consumption. Bakery products are often high in energy and fat and the most consumed bakery products is cookies. Generally, cookies contain high energy, low level of other nutrition, and are made from wheat flour (Toan and Thuy, 2018). The substitution of wheat flour with high fibre flour can increase the fibre content in cookies (Jesmin et al., 2016). Adequate fibre consumption is necessary to prevent the risk of cardiovascular disease, stroke, hypertension, and diabetes mellitus. Adequacy of fibre intake in various countries in the world is still less than the WHO recommendation of $25 \mathrm{~g} /$ day. 
Therefore, there is a need to develop high fibre foods with low energy content to overcome several diseases caused by lack of fibre (Rismaya et al., 2018). Since cookies are favoured in Indonesia, the development of high fibre cookies should be given attention. Due to the high fibre content of yellow pumpkin and mocaf flour, these flours will be used to substitute wheat flour. The aims of this study are to develop high fibre cookies made from yellow pumpkin flour and mocaf flour and to evaluate the proximate analysis of the cookies. In addition, sensory evaluation of the cookies will be conducted to determine the acceptability.

\section{Materials and methods}

\subsection{Cookies preparation}

Cookies were developed from two formulations whereby Formulation 1 (F1), 1: 2 ratio of yellow pumpkin flour to mocaf flour and Formulation 2 (F2), 1: 2 ratio of yellow pumpkin flour to wheat flour. The formulations of cookies are as shown in Table 1 . Margarine and refined sugar were mixed for 10 mins. Egg yolk was then added and mixed until homogenous. Respective flours according to ratio were added in with corn starch, milk powder, baking powder, cinnamon, and oatmeal. Ground fried cashews were then added, and the dough was kneaded until smooth. The dough was portioned of $5 \mathrm{~g}$ and roasted at $140^{\circ} \mathrm{C}$ for 10 mins until cooked.

Table 1. Cookies formulation

\begin{tabular}{lcc}
\hline Ingredients & Formula 1 & Formula 2 \\
\hline Margarine & $150 \mathrm{~g}$ & $150 \mathrm{~g}$ \\
Alternative sweeteners & 2 sachets & 2 sachets \\
Egg yolk & 1 & 1 \\
Wheat flour & $100 \mathrm{~g}$ & - \\
Mocaf flour & - & $100 \mathrm{~g}$ \\
Yellow Pumpkin flour & $50 \mathrm{~g}$ & $50 \mathrm{~g}$ \\
Salt & $1 / 4$ teaspoon & $1 / 4$ teaspoon \\
Maize & $30 \mathrm{~g}$ & $30 \mathrm{~g}$ \\
Milk powder & $30 \mathrm{~g}$ & $30 \mathrm{~g}$ \\
Baking powder & $1 / 4$ teaspoon & $1 / 4$ teaspoon \\
Cinnamon powder & $1 / 2$ teaspoon & $1 / 2$ teaspoon \\
Oatmeal & $50 \mathrm{~g}$ & $50 \mathrm{~g}$ \\
Cashew nut & $50 \mathrm{~g}$ & $50 \mathrm{~g}$ \\
\hline
\end{tabular}

\subsection{Nutrition analysis}

The nutrition analysis test was conducted at the chemistry laboratory, Faculty of Science and Mathematics, Satya Wacana Christian University Salatiga including the fat analysis (AOAC Method No 900.02), protein analysis (AOAC Method No 934.01), carbohydrate analysis (AOAC Method No 960.52), and fibre analysis (AOAC Method No.991.43) (AOAC,
2000).

\subsubsection{Carbohydrate}

Carbohydrate analysis test used the anthrone method, anthrone, dehydro-ketoanthrone, regulates by selecting the turquoise colour and arranged uptake with a spectrophotometer.

\subsection{Sensory analysis}

A total of twenty-five panellists, consisting of the students of Ngudi Waluyo University in the nutritional study program, were invited to conduct the sensory analysis. Panellists were asked to evaluate the flavour, aroma, texture and colour using a 5-point hedonic scale $(1=$ dislike extremely $-5=$ like extremely $)$ for each attribute.

\subsection{Statistical analysis}

All statistical analysis was performed using SPSS 16 computer program from Windows. Mann Whitney test was used to determine the significant difference.

\subsection{Ethical clearance}

Request ethical clearance has been reviewed and approved by Faculty of Public Health Semarang State University with the certificate number 201/KEPK/EC/2019.

\section{Results and discussion}

\subsection{Nutrition analysis}

The results of nutrition analysis obtained nutritional content of pumpkin cookies with flour and pumpkin cookies with mocaf flour which can be seen in Table 2 . A cookie recipe can produce sixty pieces weighing $5 \mathrm{~g}$ each. Figure 1 shows the pumpkin cookies with wheat flour (F1) and Figure 2 shows the pumpkin cookies with mocaf flour (F2). Table 2 shows that the protein content of pumpkin cookies with wheat flour was higher than the protein content of pumpkin cookies with mocaf flour. This can be influenced by the protein content of wheat flour which is higher than the mocaf flour. A previous study by Amanu and Susanto (2014) showed that the protein content of mocaf flour was $2.45 \mathrm{~g} / 100 \mathrm{~g}$ while the protein content of wheat flour based on Indonesian food composition tables was $8.9 \mathrm{~g} / 100 \mathrm{~g}$ (Indonesian Food Composition Table, 2018).

The fat content in pumpkin cookies with wheat flour is higher than the pumpkin cookies with mocaf flour, the fat content of both formula cookies was from margarine and the added milk. The maximum fat requirement for a weight loss diet is $50 \mathrm{~g}$ /day (Lysen and Israel, 2017), the pumpkin cookies made from F1 (16.34\%) and F2 
Table 2. Nutritional value of pumpkin cookies

\begin{tabular}{lcccc}
\hline \multicolumn{1}{c}{ Nutrient } & F1 $/ 100 \mathrm{~g}$ & $\mathrm{~F} 1 / 40 \mathrm{~g}$ & $\mathrm{~F} 2 / 100 \mathrm{~g}$ & $\mathrm{~F} 2 / 40 \mathrm{~g}$ \\
\hline Energy & $587.72 \mathrm{kcal}$ & $117.54 \mathrm{Kcal}$ & $459.71 \mathrm{kcal}$ & $91.94 \mathrm{kcal}$ \\
Protein & $4.79 \mathrm{~g}$ & $0.95 \mathrm{~g}$ & $1.12 \mathrm{~g}$ & $0.22 \mathrm{~g}$ \\
Fat & $40.87 \mathrm{~g}$ & $8.17 \mathrm{~g}$ & $36.35 \mathrm{~g}$ & $7.27 \mathrm{~g}$ \\
Carbohydrate & $50.19 \mathrm{~g}$ & $10.03 \mathrm{~g}$ & $31.94 \mathrm{~g}$ & $6.38 \mathrm{~g}$ \\
Fibre & $21.42 \mathrm{~g}$ & $4.2 \mathrm{~g}$ & $43.59 \mathrm{~g}$ & $8.7 \mathrm{~g}$ \\
\hline
\end{tabular}

(14.54\%) can meet the requirement.

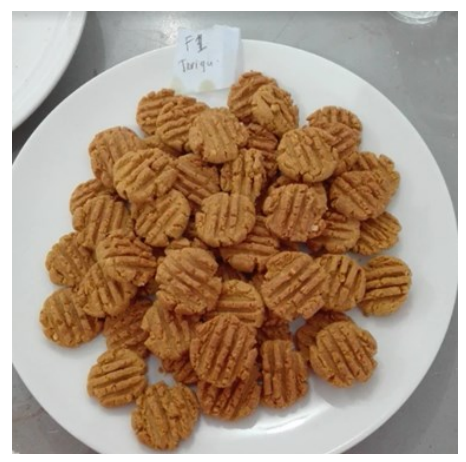

Figure 1. Pumpkin cookies with wheat flour (F1)

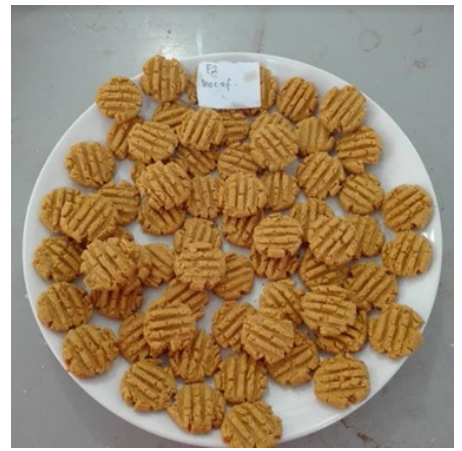

Figure 2. Pumpkin cookies with mocaf flour (F2)

The carbohydrate content of wheat flour and mocaf flour is not much of a difference. The carbohydrate content of wheat flour is $77.3 \mathrm{~g} / 100 \mathrm{~g}$ while the mocaf flour is $75.49 \mathrm{~g} / 100 \mathrm{~g}$ but the carbohydrate content of pumpkin cookies with wheat flour (4.05\%) turns out to be higher than pumpkin cookies with mocaf flour $(2.57 \%)$. The recommended carbohydrate requirement for weight loss is $50-55 \%$ of the total daily energy or 225 $\mathrm{g}-247.5 \mathrm{~g}$ for an energy requirement of $1800 \mathrm{kcal} /$ day. From the conversion energy of the protein, energy and fat content, the energy content produced by pumpkin cookies with wheat flour is $587.72 \mathrm{kcal}$ while the energy content of pumpkin cookies with mocaf flour is 459.71 $\mathrm{kcal}$. The serving portion of pumpkin cookies is $20 \mathrm{~g}$ which is equivalent to the serving size of existing commercial cookies that are claimed for weight loss diets. The nutritional value of each serving size can be seen in Table 2.

The food contains low energy if it only contains 40 kcal (Food and Drugs Adminstration, 2019). According to nutrient analysis, pumpkin cookies are not included in low-energy snacks because they have an energy content of more than $40 \mathrm{kcal}$ for each serving. However, when compared with the recommended maximum snack for obesity which is $150 \mathrm{kcal}$, pumpkin cookies can be one of the alternative snacks for consumption. The energy content per serving $(20 \mathrm{~g})$ of pumpkin cookies with Mocaf flour is $91.94 \mathrm{kcal}$ and fibre $8.7 \mathrm{~g}$. If we compared with commercial cookies product, the content energy is $100 \mathrm{kcal} /$ serving and the fibre is $2 \mathrm{~g} /$ serving, the pumpkin cookies with mocaf flour have lower in energy and higher in fibre.

Minister of Health Regulation of the Republic of Indonesia No. 75 of 2013 article 4 states that the total energy needs of the average Indonesian population is $2150 \mathrm{kcal} / \mathrm{person} /$ day (Permenkes, 2013). Thus, the serving size $(20 \mathrm{~g})$ of cookies can meet $5.4 \%$ (F1) and $4.2 \%$ (F2) of the average energy needed by the Indonesian population per person per day. The recommended energy requirement for obesity is 1200 $1800 \mathrm{kcal} / \mathrm{day}$, so pumpkin cookies can meet $6.5 \%$ and $5.1 \%$ of the maximum needs of obese individuals (Lysen and Israel, 2017).

The fibre content of pumpkin cookies with mocaf flour is higher than pumpkin cookies with wheat flour, the fibre content can be influenced by the addition of pumpkin flour and oats. Fibre component of the pumpkin consists of pectin, cellulose, hemicellulose and lignin (Wongsagonsup et al., 2015). The fibre content of mocaf flour is higher than wheat flour, therefore, pumpkin cookies with mocaf flour have higher fibre content. If the fibre content in a portion of food contains $3 \mathrm{~g} / 100 \mathrm{~g}$, it is classified as a food source of fibre and high in fibre as the food fibre content is as much as 6 g/100 g (Indonesian Food and Drug Administration, 2016). The daily fibre required is $25 \mathrm{~g} /$ day and the consumption of pumpkin cookies can help to meet the requirement as they contain fibre as much as $16.8 \%(\mathrm{~F} 1)$ and 34\% (F2). Meal replacement therapy for obesity should also meet the fibre requirement which is at least 5 $\mathrm{g} /$ serving. Hence, pumpkin cookies with mocaf flour can be recommended as a snack for obese consumers.

\subsection{Sensory analysis}

The hedonic test results on cookies based on the Mann Whitney statistical test showed that there were no statistical significant difference in texture, taste, colour and aroma in the pumpkin cookies with wheat flour (F1) and pumpkin cookies with mocaf flour (F2). Table 3 
shows that the preference level of panellist for the pumpkin cookies and most panellists are able to accept the cookies. The differences between two cookie formulations are in the amount of wheat flour and mocaf flour added. Based on the hedonic test, the two cookie formulations are liked by panellists. Therefore, mocaf flour can replace wheat flour and pumpkin flour can be used as the basis for making cookies.

Table 3. Sensory evaluation of pumpkin cookies

\begin{tabular}{ccccc}
\hline Formula & Texture & Flavour & Colour & Aroma \\
\hline F1 & $3.12 \pm 0.78$ & $3.36 \pm 0.81$ & $3.44 \pm 0.82$ & $3.76 \pm 0.83$ \\
F2 & $3.16 \pm 0.85$ & $3.28 \pm 0.61$ & $3.52 \pm 0.71$ & $3.52 \pm 0.77$ \\
Result & $\mathrm{p}=0.92$ & $\mathrm{p}=0.96$ & $\mathrm{p}=0.52$ & $\mathrm{p}=0.26$ \\
\hline
\end{tabular}

Values are mean \pm standard deviation

The preferred texture of cookies is crispy when it is broken. The Mann-Whitney test showed a result of $p>$ 0.05 which showed that there was no difference in texture in pumpkin cookies with mocaf flour or wheat flour. Cookie texture is formed by fat and amylose content. The fat in cookies will break down the amylose structure then cover the starch and gluten to produce crispy cookies (Oktaviana et al., 2017). In this research, the wheat flour and mocaf flour used was $50 \mathrm{~g}$ and they produced a texture that is preferred by panellists, so it can be concluded that the mocaf flour can provide the same crispy texture as wheat flour.

The taste of food is strongly influenced by the composition of the ingredients used. The Mann-Whitney test showed $p>0.05$ which showed that there was no difference in taste in pumpkin cookies with mocaf flour or wheat flour. The taste of pumpkin cookies is influenced by a pumpkin that has a sweet basic taste. The use of less sugar does not add excessive energy value and the taste will not be too sweet so that it can be liked by panellists. Other basic ingredients that affect the taste are the addition of eggs, margarine, and mocaf flour or wheat flour.

Colour is the first factor in assessing a food preference test because it is a visual appearance. The Mann-Whitney test showed $p>0.05$ meaning that there was no colour difference in pumpkin cookies with mocaf flour or wheat flour. The colour of pumpkin cookies is yellow because of the ingredients. The comparison of pumpkin and flour by 1: 2 in both formulations of cookies gave a yellow effect that is not concentrated, but when it went through the roasting process with the same temperature and time, the pumpkin cookies with wheat flour has a brownish colour compared to pumpkin cookies with mocaf flour.

The Mann-Whitney test showed $p>0.05$ which showed that there was no difference in aroma in pumpkin cookies with mocaf flour or wheat flour. Pumpkin has a distinctive aroma. Besides, the aroma of cookies is influenced by the starch content of wheat flour and mocaf flour so that a Maillard reaction occurs. Maillard reactions that occur during the roasting process produce a distinctive and preferred product aroma. The higher the protein content of the material used, the stronger the aroma produced from the Maillard reaction. The aroma of cookies is also strengthened by the use of margarine in the dough. Fat is an important component in making cookies because it functions as an aroma enhancer (Maerunis, 2012).

\section{Conclusion}

According to the colour, aroma, texture and taste, the acceptance of pumpkin cookies with mocaf flour is no different from pumpkin cookies with wheat flour. The result showed that the use of wheat flour in bakery products in making cookies can be substituted by mocaf flour. The energy content of pumpkin cookies with mocaf flour substitution is lower than pumpkin cookies with wheat flour. The fibre content of the pumpkin cookies with mocaf flour is higher than the pumpkin cookies with wheat flour. Pumpkin cookies with mocaf flour are qualified as a high-fibre food with the fibre content of $6 \mathrm{~g} /$ serving. The energy content of pumpkin cookies with mocaf flour is lower than the energy content of commercial cookies for weight loss diets.

\section{Conflict of interest}

The authors declare no conflict of interest.

\section{Acknowledgements}

The authors would like to thank Ngudi Waluyo University for funding this research.

\section{References}

Amanu, F.N. and Susanto, W.H. (2014). MOCAF Production in Madura (Study of Varieties and Plantation Sites) Toward Quality and Yield. Jurnal Pangan Dan Agroindustri, 2(3), 161-169.

Basic Health Research (2018). Ministry of Health Republic of Indonesia. Health research and development agency. Retrieved from the Ministry of Health Republic of Indonesia: http:// kesmas.kemkes.go.id/assets/upload/ dir_519d41d8cd98f00/files/Hasil-riskesdas2018_1274. pdf

Food and Drugs Adminstration. (2019). Nutrient content claims for the calorie content of foods. Retrieved from FDA website: https://www.accessdata.fda.gov/ 
scripts/cdrh/cfdocs/cfcfr/CFRSearch.cfm?fr=101.60

Foschia, M., Peresinni, D., Sensidoni, A. and Brennan, C.S. (2013). The Effect of Dietary Fibre addition on The Quality of Common Cereal Products. Journal Cereal Science, 58(2), 210-227. https:// doi.org/10.1016/j.jcs.2013.05.010

Hanifa, R., Hintono, A. and Pramono, Y.B. (2013). Protein Total, Calcium, and likes to Taste of Chicken Nugget from The Substition Wheat Flour with Mocaf and Bone. Journal of Nutrition and Food, 4 (8), 53-60.

Indonesian Food and Drug Administration. (2016). Regulation Head of Indonesian Food and Drug Administration Number 13 of 2016 Concerning Supervisor of claims in the labeling and advertisement of processed food. Retrieved from Indonesia Food and Drug Administration website: http:// standarpangan.pom.go.id/dokumen/ peraturan/2016/

PerKa_BPOM_No_13_Tahun_2016_tentang_Klaim pada_Label_dan_Iklan_Pangan_Olahan.pdf

Indonesian Food Composition Table. (2018). Ministry of Health Republic of Indonesia. Retrieved from the Ministry of Health Republic of Indonesia website: http://www.panganku.org/id-ID/cari_nutrisi

Jesmin, A.M., Ruhul, A.M. and Chandra, M.S. (2016). Effect of Pumpkin Powder on Physico-chemical Properties of Cake. International Research Journal of Biological Sciences, 5(4), 1-5.

Permenkes. (2013). Minister of health Regulation. Recommended Dietary Allowance For Indonesia. Retrieved from the Ministry of Health Republic of Indonesia website: https://peraturan.bkpm.go.id/jdih/ userfiles/batang/PMK\%20No.\%2075\%20ttg\%

20Angka $\% 20$ Kecukupan $\% 20$ Gizi $\% 20$ Bangsa $\%$ 20Indonesia.pdf

Purnamasari, I.W. and Putri, W.D.R. (2015). The Effect of Pumpkin Flour and Addition of Sodium Bicarbonate on Taro Flakes Characteristics. Jurnal Pangan dan Agroindustri, 3(4), 1375-1385.

Lysen, L.K. and Israel, D.A. (2017). Nutrition in Weight Management. In Mahan, L.K. and Raymond, J.L. (Eds). Krause's Food and the Nutrtion Care Process. $2^{\text {nd }}$ ed., p. 383-404. USA: Elsevier.

Maerunis. (2012). Pengaruh Suhu dan Lama Pengeringan Terhadap Kuantitas dan Kualitas Pati Kentang Varietas Granola. Jurnal Teknologi dan Industri, 4 (3), 26-30. [In Bahasa Indonesia].

Oktaviana, A.S., Hersoelistyorini and Nurhidajah. (2017). Protein Content, Growth Power and Organoleptic Cookies with Substitution Mocaf and Flour of Banana's Kepok. Jurnal Pangan dan Gizi, 7
(2), 72-81.

Rismaya, R., Syamsir, E. and Nurtama, B. (2018). The Effect pumpkin Flour Addition to fiber, PhysicoChemical and Muffin Sensory. Jurnal Teknologi dan Industri Pangan, 29(1), 58-68. https:// doi.org/10.6066/jtip.2018.29.1.58

Statistics Indonesia. (2012). Statistic of Seasonal Vegetebles and Fruits Plants. Retrieved from Badan Pusat Statistik website: https://www.bps.go.id/ publication/download.html?nrbvfeve

Tanjung, Y.L.R. and Kusnadi J. (2015). Free Gluten Biscuit and free casein for Autism. Jurnal Pangan dan Agroindustri, 3(1), 11-22.

Toan, N.V. and Thuy, N.T.T. (2018). Production of High Quality Flour and the Made from Pumpkin. International Journal of Food Science and Nutrition, 3(5), 157-166.

Wongsagonsup , R., Kittisuban, P., Yaowalak, A. and Suphantharika, M. (2015) Physical Sensory Qualties of Composite Wheat Pupmpkin Flour Bread with Addition of Hydrocolloids. International Food Research Journal, 22(2), 745-752. 